\title{
ENTREPREUNEURSHIP EDUCATION IN PORTUGAL - CONSIDERATIONS ON THE TOPIC AND ITS DEVELOPMENT ENVIRONMENT
}

\author{
H. SARAIVA ${ }^{*}$ and T. PAIVA
Instituto Politécnico da Guarda - Portugal
helenasaraiva@ipg.pt \\ Article received November/2014 and accepted in December/2014 \\ DOI: $10.15628 /$ holos.2014.2587
}

\section{ABSTRACT}

The role and importance of entrepreneurship as a booster of economic development has been recognized over time, in line, among others, with Schumpeter (1934), Leibenstein (1968), Kirzner (1997), Baumol (2002) and Acs et al. (2004). The establishment of new businesses is searched and needed, particularly in an economic context such as we are currently living, and this places emphasis on the issue of entrepreneurship education at our schools, which necessarily involves discussion and debate on the topic in order to ensure that results can actually lead us to reach the intended goals. If, on one hand, in Portuguese higher education system can already be found some programs and projects to teach how a business should be thought through and scheduled, on the other hand, presently the discussion consists in the possibility of integration of the entrepreneurship subject on previous levels of education, where the programs contents' are broader, more global and less specific. This has lead to a
\end{abstract}

discussion on the definition of entrepreneurship, and apparently the option to integrate this issue in primary and secondary education appears to be in line with inducing and facilitating the setting up of attitudes, rather than acquiring business expertise or achieving skills in the economic sphere. Some authors - Hofstede (2001), George and Zahra (2002), Silva et al. (2009) stated that cultural issues are one of the factors determining and driving entrepreneurial behavior, raising the question that teaching strategies ought to take these conditioning factors into account. The present paper aims to give a brief characterization of entrepreneurship education, particularly in Portugal, and to reflect on how cultural issues can and should guide the teaching strategies and future programs or projects designed to promote the entrepreneurial mind and attitudes at all education levels within the considered territory. 


\section{INTRODUCING}

The role of entrepreneurship in terms of economic development has been renowned for various theorists through time, among them Schumpeter (1934), Leibenstein (1968), Kirzner (1997), Baumol (2002) and Acs et al. (2004).

Entrepreneurship's definition often figures by referring to the attitudes towards the surrounding environment and the ability to respond to such environment, in order to build solutions wich happens to add value into society. For the European Union (2012), entrepreneurship regards the individual ability to turn ideas into actions, and such ability requires creativity, innovation and risk taking, as well as entails the capability to plan and manage projects with the purpose of achieving aims and targets. The same source considers that this bears daily activities, either personally or socially, makes workers more aware of the context of their own work and most apt to seize opportunities, by providing a basis to entrepreneurs to establish a social or commercial activity.

Converging with this direction Poikkijoki and Heinonen (2006) state that entrepreneurial behavior has been widespread, and this is related with the appeal to larger and better entrepreneurial competencies in order to face mounting challenges and future's uncertainty.

According to those authors, the attributes related to entrepreneurial activity, aiming the creation of viable platforms for the development of societies, consist on high readiness for change, self-confidence and creativity, as well as an innovative approach to address problems.

Literature seems to suggest that entrepreneurship behaviour is limited and/or influenced by several factors, being one of them the national cultural characteristics of the country in wich entrepreneurs are in and born and raised (Tan, 2002). Busenitz and Lau (1996), cit. in George and Zahra (2002), state that studies of transcultural research try to understand how culture may influence entrepreneurial activities. Another aspect highlighted in literature is the apparent tendency in recent research, to study and try to understand how entrepreneurs think and make decisions due to cultural aspects (George and Zahra, 2002).

Most researches related to entrepreneurship, entrepreneurs' characteristics and national culture base their models upon Hofstede cultural dimensions (Hayton et al., 2002). The five cultural dimensions considered by Hofstede (2001) consist on: power distance, individualism and collectivism, masculinity and femininity, uncertainty dislike, and orientation towards long term or short term. Hofstede (2001) found that Portuguese culture is most expressively characterized by the dimensions of power distance and uncertainty dislike, and especially by the last one.

Generally, research made on the subject shows that entrepreneurial activity level is favored in cultures with low power distance and low uncertainty dislike, high individualism and masculinity (Hayton et al., 2002). By these authors, high uncertainty dislike and high power distance, precisely the ones identified by Hofstede as the main cultural dimensions in our country, are inhibitor of entrepreneurial activities, whereas high individualism and masculinity are stimulus. Those cultures which value and enhance self-realization, autonomy and material conquest are, in a general way, the ones that achieve higher rates in businesses establishment. 
According to Monteiro da Silva et al. (2009), Hofstede relates high power distance to power's centralization which inhibits entrepreneurship. Whereas, low power distance is associated to decentralization, being this a stimulus to entrepreneurship. The same way, high uncertainty dislike enhances restrictive roles and extreme formal procedures, which are also negative issues when relating to entrepreneurial initiative. On the other hand, a society that shows low uncertainty dislike becomes more capable to understand and seize opportunities, and this is fundamental to increase rates of entrepreneurship. As for masculinity, and since this is a competitive feature, of endurance and struggle for existence, it is positively associated with a higher level of entrepreneurship, in opposition to femininity

The notion of innovation has been constantly linked to different aspects of entrepreneurship - in most developed economies, the long-term economic growth relies increasingly on enterprise creation and on the fact that they generate innovation in terms of products, services and processes. The process of innovation is closely linked with the concept of businesses, because their creation is, itself, an innovation (Drucker, 1985). As for innovation intensity, it differs depending on the company which originates it, since organizations' motivation for producing innovations is to create value, thereby increasing their competitiveness and promoting their survival (Mulet, 2011). In this sense initiatives not exclusively based on innovation, but also in replication, will also take relevance (Kirzner, 1997).

Thus it is important to establish that relationship seems to exist between the activities of established businesses and the creation of new business initiatives, linking these issues with the national growth of countries - Reynolds et al. (1999).

Therefore the establishment of businesses takes great relevance and importance. New companies bear the mechanisms of increased competitiveness and economic growth, and it is for this reason that the European Union has boosted support to general government for setting up innovative businesses and activities, being the primary purpose of the Europe's 2020 Strategy.

One of the ways in which public authorities have been working to achieve this goal is through entrepreneurship education practice extended to most of the EU countries.

The aim of this paper is just to undertake an analysis on the evolution of the formative experiences on entrepreneurship, within the European Union and to compare it with the developments of the same in Portugal.

To answer this investigation question - how has entrepreneurship education evolved, especially in countries of the European Union, in general, and in Portugal, in particular, during the past few years - we have conducted an analysis of the literature on scientific papers and official documentation, coming either from the European Union or from national institutions.

The methodology used in the present paper was bibliographical and documental analysis, with recourse to several databases, including the Scientific Open Access Repository of Portugal Repositório Científico de Acesso Aberto de Portugal (RCAAP), as well as the Eurydice database, and the Global Entrepreneurship Monitor (GEM) database, in order to identify the main educational practices generally pursued in the territories identified and their respective outcomes. 
This paper is organized as follows: initially it is mainly addressed the point of education for entrepreneurship and its' respective framework and guidelines, then it is carried out an overview on the developments in this kind of teaching within the European Union and then comes the analysis on the evolution of this kind of education in Portugal. Lastly the main outcomes are identified, subsequently being set out the conclusions and suggestions for further work on the subject.

\section{ENTREPRENEURSHIP EDUCATION}

According to Levie and Autio (2008), the key issue from the standpoint of entrepreneurship research is not who are entrepreneurs, but rather how they develop their action, under which circumstances and with what effects. In this sense education and entrepreneurship training has been one of the most studied and used ways to leverage business activity. Such education and training activities, conducted specifically for entrepreneurialism, have generally the purpose of increasing the supply of entrepreneurship across different mechanisms which normally are linked to: the transmission of instrumental skills necessary to start and grow a new business (Honig 2004); as well as by strengthening cognitive abilities to handle the complexity involved in recognizing and assessing business opportunities (Detienne and Chandler, 2004); and also by the cultural effects on people, such as attitudes and behavioral dispositions (Peterman and Kennedy, 2003).

Regarding the models that have been followed to compose the entrepreneurship notion, its teaching and their outcomes, one of the most widespread and accepted is that of Poikkijoki \& Heinonen (2006), which has been used by the European agency for education, audiovisual and culture (Education, Audiovisual and Culture Executive Agency - EACEA). This model employs three perspectives as the anchors than an entrepreneurial activity should assume: attitudes, knowledge and ability to act.

Although some authors (Béchard and Grégoire, 2005), had highlighted the fact that even with education being one of the issues most studied and discussed in entrepreneurial literature, its effects in terms of entrepreneurial activity of the populations would not have been still clearly stated; yet, there are another authors who assert precisely the opposite (Levie and Autio, 2008): the real impact of training and teaching entrepreneurship is verified either by the influence exerted in the population of a country, in terms of the ability to recognize and seize economic opportunities business, or through the fact that this kind of training infuse on individuals the skills and technical expertise required to support the onset of companies.

Other authors (Audretsch et al., 2007), further consider there is a general consensus on the fact that entrepreneurship consists on a liable phenomenon, at the national and regional level, to be influenced by political decision makers, with the attention and knowledge bestowed by those, positively associated with the allocation of efforts devoted to increase entrepreneurship. In this sense, Leibenstein (1968), asserts that should be taken into account at this level, not only barriers to entrepreneurial activity, but also that the policies should be focused in strengthening the market efficiency and promoting an environment able to motivate entrepreneurs. 
Therefore, it will be crucial, in our opinion, in addition to the creation of the circumstances required to encourage entrepreneurship, also to establish a culture to support entrepreneurship activities, namely, boosting the development of individual capabilities to recognize opportunities by passing the information needed to identify these opportunities and the cognitive properties necessary to cherish them. According to Shane and Venkataraman (2000), the input of information required must be impounded based on a background on the user's requirements in certain areas; as for the cognitive properties they should match to the individual ability to process the information taken from social interaction taking place in the market.

Whether the entrepreneur shall be able, or not able, to perceive the opportunities at a given moment or situation, it will depend on its own ability to understand, analyze and realize the responses delivered by the market. Processing these mechanisms is critical even before any response from the market, leading to facilitate and guide the actions, by providing insight into how to take advantage of a situation, resource or unfulfilled need. Thereby, entrepreneurship education should leverage the development of cognitive capacities requested to meet market opportunities. All training and education for this issue shall provide to individuals the contact with histories and cases of discovery and exploration of entrepreneurial opportunities, by giving examples to the students that they can use as a reference when they themselves do might encounter unsatisfied needs or non appreciated resources.

\section{ENTREPRENEURSHIP EDUCATION IN THE EUROPEAN UNION}

The model presently accepted and implemented in the European Union to compose the notion of education in entrepreneurship is based on that proposed by Heinonen and Poikkijoki (2006), and takes as its main objective to give students the attitudes, knowledge and skills for acting in an entrepreneurial way, taking the various dimensions of entrepreneurship education from being unfolded into several categories, that provide the framework of different learning outcomes achieved by EU countries, namely:

\section{Attitudes:}

Category 1 - self-awareness and self-confidence - are the basic attitudes required for every other aspects concerning to entrepreneurship - involves the discovery and trust in individual skills which enable subsequently turn creative ideas into actions. In many countries such attitudes are pursued as goals of general education.

Category 2 - Taking the initiative, risk-taking, critical thinking, creativity and problem solving, are also key aspects to an entrepreneurial attitude.

Knowledge:

Category 1 - The knowledge of career opportunities and labor market are learning outcomes which are not exclusively related to entrepreneurship, being also part of the overall preparation of the students at preparing their future careers; this kind of awareness is still required to realize the meaning of being an entrepreneur, since they involve knowledge of the nature of work and the different types of labor, contributing such knowledge for the assessment of opportunities and threats.

Category 2 - Economic and financial literacy, including the knowledge of concepts and processes relevants to entrepreneurship. 
Category 3 - knowledge about business organization and processes - this is regarded as specific to the environment in which entrepreneurship is developed.Skills:

Category 1 - Communicating, presenting and planning, as well as the ability to work in groupall regarded as transversal competencies for entrepreneurs.

Category 2 - Exploring entrepreneurship opportunities - taking into account the different stages of setting up a business - including design and implementation of a business plan.

Adapted from: Eurydice network, Entrepreneurship Education at School in Europe National Strategies, Curricula and Learning Outcomes, March 2012, p.19.

These dimensions and categories have been used in entrepreneurship education in the EU countries, in full or in part, either at primary education or secondary level, or both simultaneously. In the reference years 2011/12, in terms of primary education, about half of the European countries defines entrepreneurship learning objectives related to the curriculum level, while in terms of secondary education, increases the number of countries who do this for all the levels for upper figures. It is also verified that, at the level of primary education, learning objectives find themselves embedded in compulsory subjects, while on the secondary education occurs precisely the opposite - i.e., on this level of education entrepreneurship issues are typically integrated in optional subjects.

Based on the Eurydice survey conducted in 2011 under the theme Education for Entrepreneurship, covering national strategies, initiatives and ongoing reforms relating to the current situation of entrepreneurship education - in which thirty-one European countries have had part - it appears that the vast majority of them includes the teaching for entrepreneurship in their systems and strategies. This seems to reflect the recognition of the importance of entrepreneurship education in Europe, where about half of the countries developed objectives by linking them to promote this kind of education embedded in broader strategies - education throughout life, education and youth, as well as growth - while other countries, including northern Europe, have developed specific strategies, as seen in Figure 1.

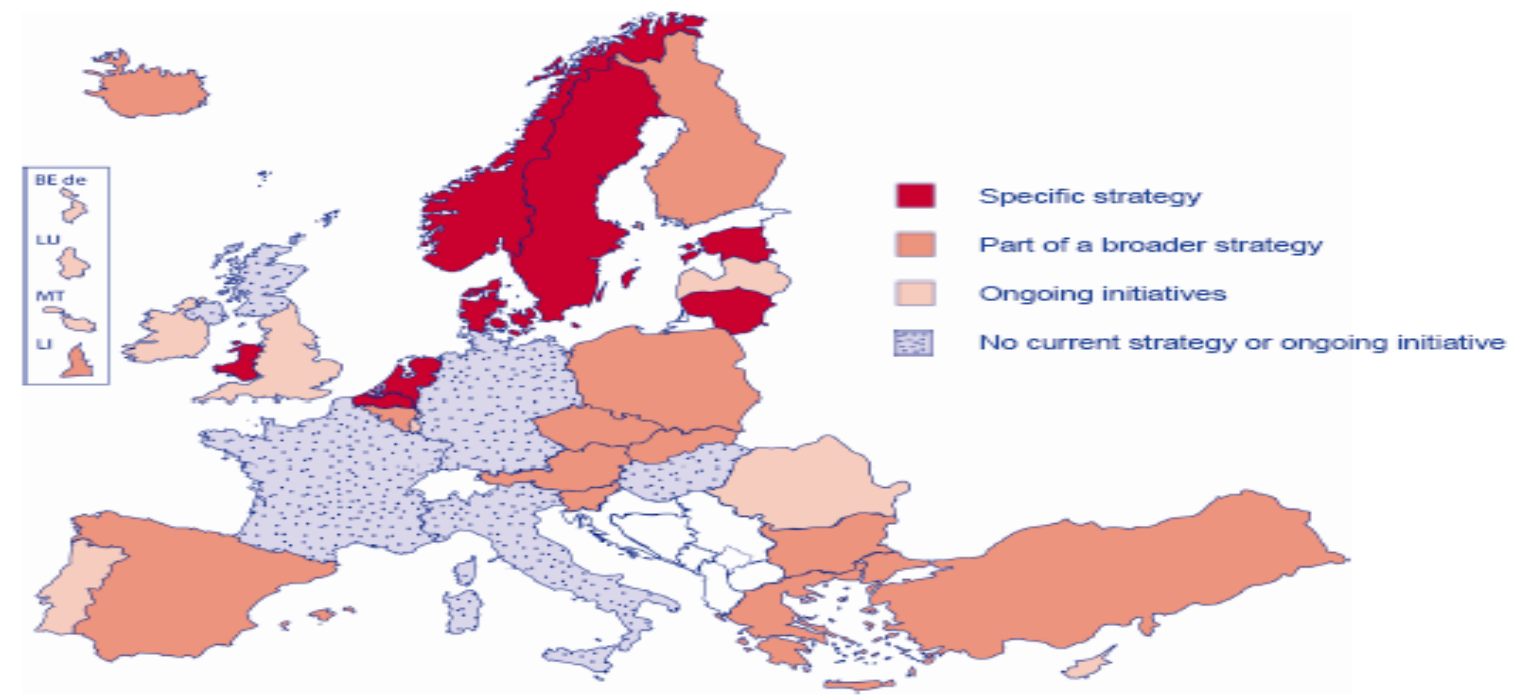

Source: Eurydice (2012), Entrepreneurship Education at School in Europe - National Strategies, Curricula and Learning Outcomes, March, Eurydice network, p.8.

Figure 1 - Strategies and initiatives to implement entrepreneurship education in EU 
In accordance with same source, two thirds of the European countries explicitly recognize entrepreneurialism in the basis documentation of the primary system, whereas in the secondary system, the theme is considered in educational documents in virtually all countries. Figure 2 shows the launch dates or startup national strategies for entrepreneurship education.

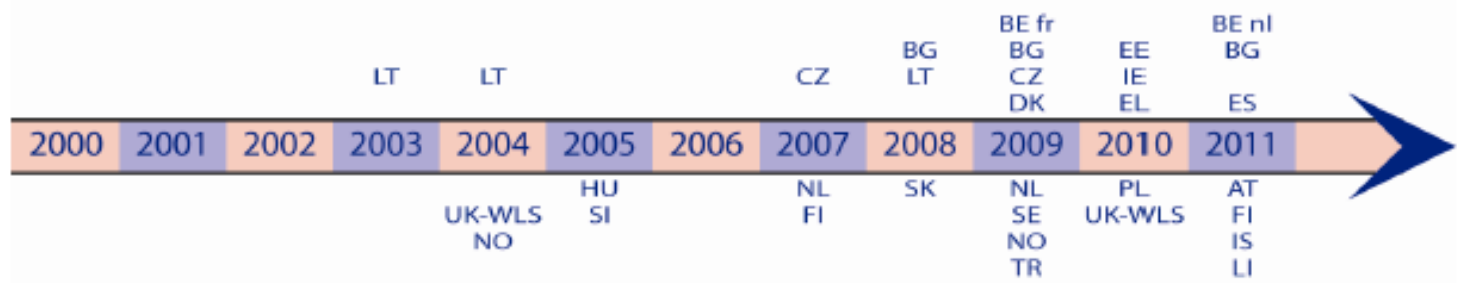

Source: Eurydice (2012), Entrepreneurship Education at School in Europe - National Strategies, Curricula and Learning Outcomes, March, Eurydice network, p.7.

Figure 2 - Startup of national entrepreneurship education strategies for general education (levels 1-3 ISCED)

Several European countries had set specific learning outcomes resulting from the process of teaching for entrepreneurship, and these results, in general, undertake different aspects of all three dimensions: attitudes, knowledge and skills.

On starting or initial level, half of all countries had set results basically related to attitudes, but also with horizontal skills; at this level no country defines outcomes related to skills in exploiting opportunities of entrepreneurialism.

Regarding to secondary education level, practically the totality of the countries in European Union established outcomes for entrepreneurship education; many countries made it on considering the three dimensions and most of them, at least two dimensions; however no country had setted results only for operating entrepreneurship opportunities. This seems to indicate that the other dimensions are needed to support this - especially in countries where this category was considered. The dimensions concerning understanding of business activity are also introduced at the same level of education.

\section{ENTREPRENEURSHIP EDUCATION IN PORTUGAL}

National Strategy for Entrepreneurship Education designed as Plano Nacional de Educação para o Empreendedorismo (PNEE) was launched in Portugal by 2006 and developed between 2006 and 2009, being implemented until 2010. This initiative has boosted cultural, organizational and personal adaptations (Teixeira, 2012).

PNEE aimed the development at secondary education level, projects to enhance entrepreneurship attitudes. The program wasn't implemented in all the schools, but it was possible to do it since in the secondary curricula there were subjects such as "Project Development" that allowed to students and teachers the opportunity to develop their projects. Several changes attained PNEE during its existence, most of them caused by the process that enabled autonomy in secondary level schools. 
PNEE was implemented by the schools' will to pursue entrepreneurial activities, yet mobilizing teachers to commit to this project was a difficult task and consequently motivating students to do it was also very difficult (Teixeira, 2010).

This shows the importance of the teachers' role, as a mediator of the learning process, as referred by Delors et al. (1996) and by The Commission of the European Union (2007), being fundamental to the development of the student's competences and abilities. Motivating students is a difficult task, especially given the dominant cultural characteristics in the country (Hofstede, 2001). In addition to these conditions, other limitations, such as that, in fact, many times school is regarded as a tool for transmitting information that competes directly with other tools considered most appealing by the students, namely television and internet (Teixeira, 2010). Teacher training in entrepreneurship appears to be a better way to deploy entrepreneurship education, but it becomes necessary to pave the way to involve teachers in the topic of entrepreneurship.

So, the overall picture in the country is that there are a number of schools that developed entrepreneurship education (EACEA, 2012). The schools referred where mainly from the secondary level on its final stages.

In complement to these, some municipalities developed local strategies to promote entrepreneurship with youngsters - in this case education levels involved were primary as well as secondary education, depending upon the initiatives implemented, such as: campaigns in schools, contests, workshops, business advisers, etc

At another level emerged the experience in higher education with the introduction of the curricular unit of entrepreneurship in several universities. The precursor of this practice seems to have been the University Fernando Pessoa, by the initiative of certain academics devoted to the field of entrepreneurship, according to Leite (2012). In that University, entrepreneurship subject started to be taught in the 90s, and later, with the reform connected with the introduction of the Bologna process, in Portuguese Higher Education, from 2006 onwards, most of the Portuguese Universities, if not the totality, subjects specifically or partially devoted to the thematic of entrepreneurship are taught.

Another important actor in this field, wich arose much earlier and from 1979, was the National Association of Young Entrepreneurs (ANJE). This association had as main objectives the liberalization of the economic system and, in particular, the development of better conditions of both youth access to business activity and a proficient exercise thereof. In this context, it was by itself established the Academy of Entrepreneurs in 1997, which has developed as from that date, together with universities and other institutions on the employment area, the evangelizing mission in favor of the entrepreneurship. This mission, broadly speaking, consisted in mobilizing the Portuguese young people to the need for a culture of initiative and risk, by setting up several initiatives such as the Young Entrepreneur Award, the Entrepreneur Fair, the Ideas Competition and the Road -Shows (ANJE, 2014).

By official documentation, entrepreneurship education is explicitly recognized as crosscurricular objective at all school levels - however, being not compulsory as such, it is only really considered if school's board decides to insert it in as part of the subject Civil Training. 
As for learning outcomes, they can be found in general guidelines and recommendations' documents for practice, applied in the context of the national curricula. They can include the development of attitudes such as self-awareness, self-confidence, initiative and risk-taking, creativity, critical thinking and problem-solving as well as transversal entrepreneurial skills like communication and team-work, and even, some learning outcomes are linked to economic and financial literacy

Recently, has been proposed a plan in which entrepreneurship education is also generically considered, being implemented since year 2011/12, named as Programa Estratégico para o Empreendedorismo e a Inovação $+E,+I$, which has been launched in 2011 . For this is not known, until now, learning outcomes resulting from entrepreneurship education.

The main results of GEM (Global Entrepreneurship Monitor) study in 2010, shown that the basic and secondary levels of education don't promote enough stimuli on students' creativity, self-sufficiency and personal initiative and doesn't fit on main economic principle neither gives enough attention to entrepreneurship subject. This study also states that the interest on entrepreneurship education has decreased between 2010 and 2007.

It seems that, nowadays, this situation is changing, since, by our opinion, several implemented projects brought awareness on entrepreneurships' items at these education levels, despite the issue of lack of structure on teaching methods.

In contrast with this, GEM (2010), evidences a noticeable quality on business and management education, as a way to ensure a solid training to create and develop new business, at the higher education level. It was stated that differences at this level, between 2007 and 2010, were an important improvement to maintain.

A big similitude was found between the national reality and the general UE countries, at the higher education level, but at the secondary level, namely on professional education, Portugal still doesn't show improvements on students' training in the startup and development of new business.

\section{CONCLUSIONS}

In due to the exposed, we can state that it is essential to establish a base structure for entrepreneurship education, especially at the primary and secondary levels, enabling the required support, in order to achieve the required attitudes to become an entrepreneur. We found that without the reset on the actual system it will be very difficult or even impossible the settlement of an entrepreneurial culture in Portugal.

This situation may be caused by the natural cultural characteristics of the Portuguese, since the characteristic on high power distance. This cultural dimension of Hofstede (2001) is related to the level of equality between people within a society and also to the level of acceptance by the less favored individuals, with relation to this uneven distribution of power. This dimension might show us that the Portuguese think that, maybe, entrepreneurship attitude is not for everyone and should be a behavior of only a few individuals. 
The uncertainty dislike, found by Hofstede (2001) in the Portuguese culture is also an inhibitor of entrepreneurship and this characteristic may explain why the level of business creation is low, even when business and management's higher education results are improving.

So, at this point, given the present scenario, we must highlight that the Portuguese challenge is to overcome a cultural inhibition to entrepreneurship, making an investment in entrepreneurship's education as a tool to implement the urgent changes in attitude and behaviour of the individuals. The strategy to pursue must be designed in a long term perspective, but it has to allow, in the near future, the continuous creation of entrepreneurial skills and abilities, carried out in a solid and underpinned way.

Regarding this, the only institution that can meet the referred aim is educational system, through its different levels, and to do so, teachers will need to turn the main actors, playing a critical role. To achieve teacher's motivation in entrepreneurship, and trough them, achieving students' motivation, is still essential.

It will be necessary to encourage change in students' behaviours, in order to accomplish a society with higher entrepreneurial culture. The interdependence between all these actors (culture, community, educators, schools, teachers and students) is crucial and can be represented as shown in figure 3.

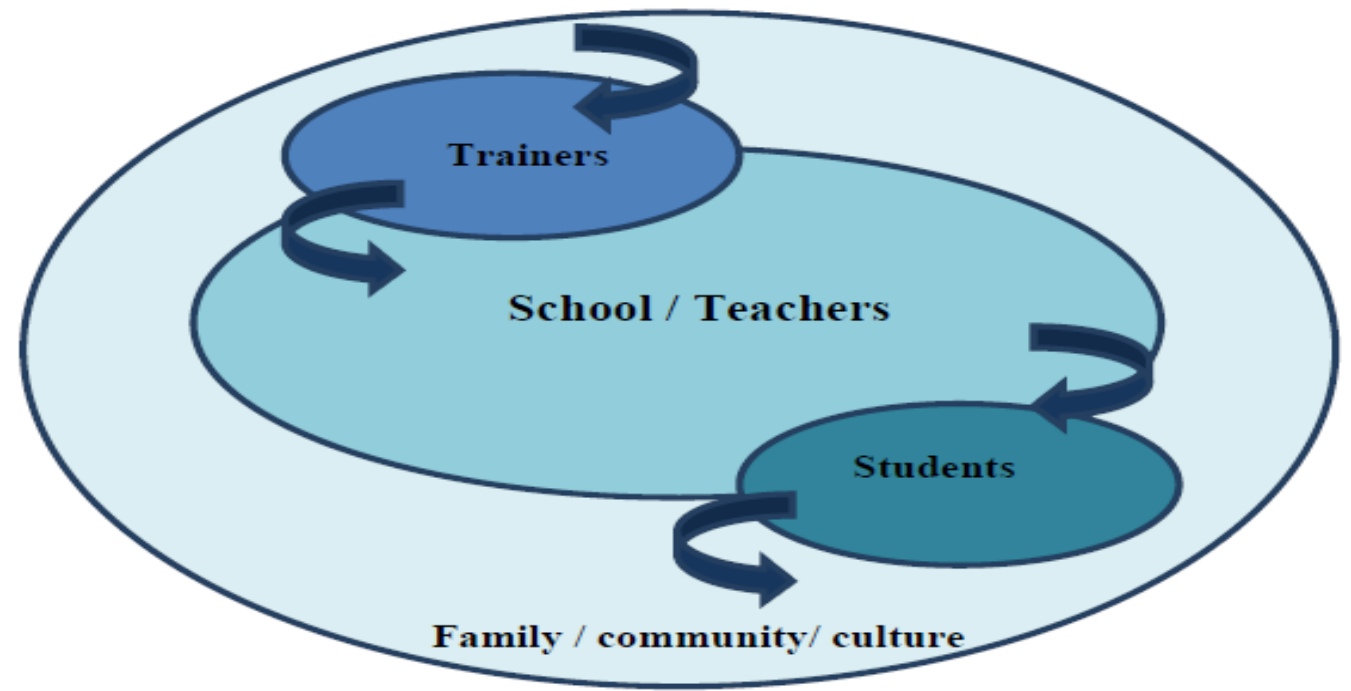

Source: adapted from Teixeira (2010).

Figure 3 - Promoting an entrepreneurial culture

It's also important to enhance that it's necessary to setup a proper environment to promote entrepreneurship education. These environmental conditions should, at first, be endorsed by the Ministry of Education, who has to develop an organizational, and curricular plan, and define the main leaders in the educational structure, without forgetting that the main goal of entrepreneurship is cultural attitude and behaviour.

So, based on all previous considerations, in our opinion, it should be settled a clear guideline to enhance the two first categories related to attitudes as defined by Heinonen and Poikkijoki (2006); self-awareness and self-confidence and taking the initiative, risk-taking, critical thinking, creativity and problem solving. This in order to overcome Portuguese traditional cultural condition's stated by Hofstede (2001). Considering that cultural conditions are a subject that 
should be addressed as soon as possible in individuals' life time, this should take place in the first educational level, i.e. in primary education. Another cultural condition stated by Hofstede (2001) is individualism - these one being positively related with entrepreneurial activities - however, one of the aspects highlighted by Heinonen and Poikkijoki (2006) is the ability to work in group. We found this last item very important since it should be cherished the condition which allows youngsters, from the beginning of their education, to act and perform embedded in networks. Being this, by the exposed, very important to act that way in the first level of educational system, it should also be deployed in primary education.

For all these reasons, the teachers' role it will be crucial, as well as their preparation and background to act in an entrepreneurial way of teaching: as a "learning facilitator" (European Commission, 2011), and as an agent of change, and being able to network making connections to a wide range of stakeholders.

Cultural values and attitudes linked to entrepreneurship behavior should be the focus to the settlement of new education strategy upon entrepreneurship. To empower Portuguese individuals since young ages and to develop competences and abilities on creativity, assessing and risk-taking, and consequently, knowing how to deal with failure or success, are very important cultural tools to a future entrepreneur.

\section{ACKNOWLEDGMENTS:}

UDI - Unidade para o Desenvolvimento do Interior*

*PEst-OE/EGE/UI4056/2014 - projeto financiado pela Fundação para a Ciência e Tecnologia (FCT)

\section{REFERENCES:}

1. ACS, Z. J., AUDRETSCH, D. B., BRAUNERHJELM, P., \& CARLSSON, B. (2004), The missing link: The knowledge filter, entrepreneurship and endogenous growth. Discussion Paper, No. 4783, December. London, UK: Center for Economic Policy Research.

2. ANJE (2014), Dossier de Apresentação - Academia dos Empreendedores, Associação Nacional dos Jovens Empresários.

3. AUDRETSCH, D. B., GRILO, I., e THURIK, A. R. (2007), Handbook of research on entrepreneurship policy, Cheltenham, UK: Edward Elgar.

4. AUDRETSCH, D., KEILBACH, M., e LEHMAN, E. (2006), Entrepreneurship and economic growth, Oxford University Press.

5. BAUMOL, W. J. (2002). The free-market innovation machine, Princeton: Princeton University Press.

6. BECHARD, J., e GRÉGOIRE, D. (2005), "Entrepreneurship education research revisited: The case of higher education", Academy of Management Learning and Education, 4(1), pp.22-49.

7. Delors, J. et al. (1996). Educação um tesouro a descobrir. Relatório para a UNESCO da Comissão Internacional sobre Educação para o século XXI. Ministério da Educação e do Desporto. Portugal. Unesco. Edições ASA. B. 9

8. DetIENNE, D., e CHANDLER, G. (2004), "Opportunity identification and its role in the 
entrepreneurial classroom: A pedagogical approach and empirical test", Academy of Management Learning and Education, 3(3), pp.242-257.

9. DRUCKER, Peter (1985), Innovation and Entrepreneurship: Practice and Principles, Harper \& Row, New York.

10. LEITE Emanuel (2012), O Fenomeno do Empreendedorismo, Editora Saraiva, Recife.

11. FIET, J. O. (2000), "The theoretical side of teaching entrepreneurship", Journal of Business Venturing, nำ16, pp. 1-24.

12. GEORGE, G. and ZAHRA, S. (2002), "Culture and its consequences for entrepreneurship". Entrepreneurship Theory and Practice, 26 (4), pp. 5-8.

13. HAYTON, J., GEORGE, G. and ZAHRA, S. (2002), "National culture and entrepreneurship: a review of behavioural research". Entrepreneurship Theory and Practice, 26 (4), pp. 33-35.

14. HEINONEN, \& POIKKIJOKI, (2006), "An entrepreneurial-directed approach to entrepreneurship education: mission impossible?" Journal of Management Development, V25, №1, pp. 80-94.

15. HOFSTEDE, G. (2001), Culture's consequences: comparing values, behaviors, institutions, and organizations across nations, $2^{\text {nd }}$ edition, Sage Publications, California.

16. HONIG, B. (2004), "Entrepreneurship education: Toward a modelof contingency-based business planning", Academy of Management Learning and Education, V3, no3, pp.258-273.

17. KIRZNER, I. (1997), "Entrepreneurial discovery and the competitive market process: An Austrian approach", Journal of Economic Literature, 35, pp.60-85.

18. LEIBENSTEIN, H. (1968). "Entrepreneurship and development", The American Economic Review, 58(2), pp.72-83.

19. LEVIE ,Jonathan and AUTIO, Erkko (2008), "A theoretical grounding and test of the GEM model", Small Bus Econ, 31, pp.235-263

20. MONTEIRO DA SILVA, Marco A. O., GOMES, Luiz F. A. M. e CORREIA, Manuela F. (2009) "Entrepreneurial Culture: a Comparative Study of Entrepreneurs in Brazil and Portugal", RAC, Curitiba, v. 13, n. 1, art. 4, pp. 57-71.

21. MULET, J. (2011): “Un diagnóstico del estado de la innovación en España”, Papeles de Economía Española, FUNCAS, núm. 27, pp. 2-12.

22. PETERMAN, N. e KENNEDY, J. (2003), “Enterprise education: Influencing students' perceptions of entrepreneurship", Entrepreneurship Theory \& Practice, 28, pp.129-144.

23. REYNOLDS, P. D., HAY, M., \& CAMP, M. S. (1999), Global entrepreneurship monitor 1999 executive report. Babson Park, MA: Babson College; London, UK: London Business School.

24. SCHUMPETER, J. A. (1934), The theory of economic development, Cambridge, Harvard University Press.

25. TEIXEIRA, Cláudia (2012), Educação para o Empreendedorismo - Um estudo sobre o Projeto Nacional de Educação para o Empreendedorismo, Tese de Mestrado, Universidade de Coimbra.

Documents: 
26. Resolução do Conselho de Ministros n. 54/2011, Programa Estratégico para o Empreendedorismo e a Inovação $+E,+I$, Anexo publicado no Diário da República, 1. a série - N.o 243 - 21 de Dezembro de 2011.

27. Education, Audiovisual and Culture Executive Agency - EACEA - (2012), Entrepreneurship Education at School in Europe - National Strategies, Curricula and Learning Outcomes, Audiovisual and Culture Executive Agency - EACEA P9 Eurydice and Policy Support, March.

28. European Comission (2012), Effects and impact of entrepreneurship programmes in higher education, Entrepreneurship Unit Directorate-General for Enterprise and Industry - European Commission, Brussels, March.

29. European Commission (2011), Entrepreneurship Education: Enabling Teachers as a Critical Success Factor - A report on Teacher Education and Training to prepare teachers for the challenge of entrepreneurship education, Entrepreneurship Unit, Directorate-General for Enterprise and Industry, Bruxelles, November.

30. European Commission (2007). Assessment of compliance with the entrepreneurship education objective in the context of the 2006 Spring Council Conclusions. Brussels.

31. http://ec.europa.eu/enterprise/policies/sme/files/support_measures/training_education/do c/edu2006_en.pdf.

32. INTUITO - Consultoria de Gestão, S.A. (2011), IES - Inovação e Empreendedorismo Sustentados - Estudo de Benchmarking Internacional, IEMINHO - Instituto Empresarial do Minho.

Sites:

33. http://entrepreneurs.about.com/gi/o.htm?zi=1/XJ\&zTi=1\&sdn=entrepreneurs\&cdn=money $\& t m=84 \& f=00 \& s u=p 284.13 .342 . i p \_p 504.6 .342 . i p \_\& t t=2 \& b t=4 \& b t s=4 \& z u=h t t p \% 3 A / / w w w . g$ emconsortium.org/, consulted in March, 2013.

34. http://eacea.ec.europa.eu/education/eurydice, consulted in November, 2012, Entrepreneurship Education at School in Europe - National Strategies, Curricula and Learning Outcomes, March 2012, Eurydice network

35. http://www.dgidc.min-edu.pt/educacaocidadania/index.php?s=directorio $\&$ pid $=48$, consulted in April, 2013.

36. http://academia.anje.pt/system/files/items/243/original/dossier_academia_2014.pdf, consultado em janeiro de 2015. 